\title{
Equivalent Selection in Specialized e-Lexicography: A Case Study with Spanish Accounting Terms
}

\author{
Pedro A. Fuertes-Olivera, University of Valladolid, Spain \\ (pedro@tita.emp.uva.es)
}

\begin{abstract}
Interest in specialized lexicography has been propelled both by the development of LSP communication in academic circles and by the consolidation of function-based approaches to lexicography that have identified the existence of several user types, e.g., experts, semi-experts and interested laypersons, and use situations, typically cognitive-oriented and communicative-oriented (Bergenholtz and Tarp, 2003, 2004). This paper follows suit and elaborates on the selection of Spanish equivalents in a particular dictionary project: the Diccionario Inglés-Español de Contabilidad, one of the Accounting dictionaries. This dictionary aims to satisfy the needs of translators (primary user group), accountants and financial experts (secondary user group), as well as students of accountancy and translation, journalists, and interested laypersons (tertiary user group). It addresses the issue as a lexicographical problem and makes comments on the decisions taken by elaborating on three lexicographical principles that take into consideration the nature of lexicography, the technical options the Internet offers, and the defining characteristics of specialized discourse: relevance, proscription and recreation.
\end{abstract}

Keywords: E-LEXICOGRAPHY, LSP LEXICOGRAPHY, TERMINOLOGY, SPANISH, ENGLISH, EQUIVALENT SELECTION, ACCOUNTING DICTIONARIES, FUNCTION THEORY, LSP COMMUNICATION, TRANSLATION DICTIONARY

Opsomming: Ekwivalent-seleksie in gespesialiseerde e-leksikografie: 'n Gevallestudie met Spaanse rekeningkundige terme. Belangstelling in gespesialiseerde leksikografie is aangevuur deur sowel die ontwikkeling van TSD-kommunikasie in akademiese kringe as die konsolidasie van funksie-gebaseerde benaderings tot leksikografie. Laasgenoemde benadering het die bestaan van verskeie gebruikerstipes, bv. kundiges, semi-kundiges en geïnteresseerde leke, en gebruiksituasies, tipies kognitief-georiënteerde en kommunikatief-goriënteerde situasies, geïdentifiseer (Bergenholtz and Tarp, 2003, 2004). Hierdie artikel volg hierdie ontwikkelings na en wei uit oor die seleksie van Spaanse ekwivalente in 'n spesifieke woordeboekprojek: die Diccionario Inglés-Español de Contabilidad, 'n rekeningkunde-woordeboek. In hierdie woordeboek word beoog om te voorsien in die behoeftes van vertalers (die primêre gebruikersgroep), rekeningkundiges en finansiële kundiges (die sekondêre gebruikersgroep), en rekeningkunde-, vertaal- en joernalistiekstudente asook geïnteresseerde leke (die tersiêre gebruikersgroep). Hierdie kwessie word aangespreek as 'n leksikografiese probleem en kommentaar word gelewer op die besluite wat geneem is deur uit te brei op drie leksikografiese beginsels wat die aard van die leksikografie, die tegniese opsies wat deur die Internet gebied word, en die definiërende eienskappe van gespesialiseerde diskoers in ag neem: relevansie, proskripsie en herskepping. 
Sleutelwoorde: E-LEKSIKOGRAFIE, TSD-LEKSIKOGRAFIE, TERMINOLOGIE, SPAANS, ENGELS, EKWIVALENT-SELEKSIE, REKENINGKUNDE-WOORDEBOEKE, FUNKSIE-TEORIE, TSD-KOMMUNIKASIE, VERTAALWOORDEBOEK

\section{Introduction: LSP Lexicography}

Although dictionary-writing is an activity with a long history, the theoretical foundations on which such an activity are carried out were not much debated until the 1990s, specifically with reference to the presentation of lexicography as an independent science (see Gouws 2011 for a review of the three stages in lexicography he comments on). Similarly, interest in specialized lexicography was almost non-existent until the publication of the Manual of Specialised Lexicography (Bergenholtz and Tarp 1995), which introduced a lexicographical approach to the study of terminology, and the establishing of departments of LSP communication in academic institutions, demonstrating the enormous potential for this field of research. For instance, certain tenets of Wüster's General Theory of Terminology could not be substantiated when specialized texts and reference works were subjected to scrutiny, which emphasized the necessity for a better understanding of the lexical component present in LSP communication.

In particular, the lexicographical approach to terminology offered arguments for discarding the often-quoted distinction between specialized lexicography and terminology, which had contributed to the presenting of specialized reference works, usually referred to as glossaries, encyclopedias, knowledge bases, term bases, etc., as alien to lexicography (Hartmann 2009). Moreover, recent research (e.g., Bergenholtz and Nielsen 2006; Fuertes-Olivera and ArribasBaño 2008; Fuertes-Olivera 2010; Fuertes-Olivera and Nielsen 2011) has assumed that specialized lexicography and terminology are two sides of the same coin, which lends support to the use of well-attested lexicographical principles when planning and compiling specialized reference works. Among these principles are the following:

- Specialized reference works must offer data for disambiguating the meaning and use of LSP terms in specific use situations, typically in cognitive-oriented and communicative-oriented. This means that the LSP dictionary should be all-inclusive, i.e., a type of dictionary that adds conceptual data to the linguistic data normally given.

- Specialized reference works can be descriptive or proscriptive. Bergenholtz and Gouws (2010), for example, advocate a proscriptive approach for text production and translation dictionaries, and a descriptive approach for text reception dictionaries.

- Specialized reference works typically address the information needs of experts, semi-experts and interested laypeople. In some use situations 
(for example, with Spanish students of Business English), the above typology merits a more detailed classification, as shown in Fuertes-Olivera and Arribas-Baño (2008).

- The distinction between culture-dependent and culture-independent subject fields is becoming blurred due to the preponderance of English loan translations, borrowings and calques in the terminologies of most languages, a fact that can be explained due to economic globalization and the consolidation of English as the lingua franca of specialized communication.

In addition, current research into LSP lexicography is also paying attention to recent developments in user-based approaches to electronic lexicography. In particular, the future of LSP lexicography seems to be subject to the combined influence of technological innovations and theoretical considerations. For example, Bergenholtz, Nielsen and Tarp (2009: 9) claim that the appearance of electronic dictionaries has lent support to function-based lexicographic theories that are centered on the dictionaries and the users, with the aim of generating new dictionaries based on the functions they must fulfill. They add that these principles

[A]pply in particular to the technical options offered by databases, text corpora, Internet searches, and Internet-based dictionaries and encyclopedias, and also to theories of and the preparation of lexicographic tools that help users meet the needs that they may have in different situations, e.g. understanding texts, producing texts, translating texts or acquiring new knowledge.

The so-called Accounting dictionaries illustrate the workings of Bergenholtz et al's reflection on a specific lexicographical project, and signal the way ahead for LSP lexicography. The Accounting dictionaries are a set of specialized Internet dictionaries that aim to satisfy the needs of translators (primary user group), accountants and financial experts (secondary user group), as well as students of accountancy and translation, journalists, and interested laypersons (tertiary user group). Several recent papers have been published in order to describe the rationale for some of the lexicographical decisions taken during planning and compilation (Nielsen and Mourier 2007), to discuss technical aspects of the accounting database that allows users to retrieve on demand (Nielsen and Almind 2011), and to explain the dynamics of accounting terms in today's world (Fuertes-Olivera and Nielsen 2011).

In addition, more focused research has also been published in relation to each of the Accounting dictionaries. For example, the Diccionario Inglés-Español de Contabilidad (Nielsen et al. 2009) has merited the attention of Fuertes-Olivera and his colleagues regarding some of its current lexicographical characteristics and future possibilities: Fuertes-Olivera (2009) has elaborated on the construction of a systematic introduction that is currently underway. Fuertes-Olivera and Niño Amo (2011) have envisaged some lexicographical options for in- 
creasing the reliability and systematicity of the dictionary. Finally, FuertesOlivera et al. (2010) have described how the concept of expert knowledge permeates the Spanish translation of the English Accounting Dictionary (Nielsen et al. 2010). Following suit, this paper elaborates on the application of a lexicographical approach to equivalent selection in specialized dictionaries, an issue that merits special attention considering that the process of equivalent selection is usually addressed from a linguistic and not a lexicographical perspective (Adamska-Sałaciak 2010).

As has already been mentioned by Bergenholtz and colleagues, nothing is more practical than a good theory (Nielsen and Tarp 2009), and so the explanations discussed here are based on the tenets of the function theory of lexicography, as well as on claims concerned with the nature of LSP communication. By so doing we add weight to two principles that permeate this paper and much of the current debate on the nature of lexicography. Firstly, lexicography is an independent academic discipline that can benefit from the options introduced by the advent of the so-called information and knowledge society. This means that we have to offer a lexicographical explanation for the options chosen when planning and compiling (Internet) information tools.

Secondly, time is ripe for discussing whether lexicography is part of information science, a change of paradigm that "could spell the beginning of the end of the underestimation of lexicography" (Bergenholtz in press), and reinforce the focus on dictionaries as tools providing assistance in various situations rather than an exercise in linguistics; in addition, it could promote "the fundamental theories that will govern the implementation of a lexicographically designed needs-adapted information and data access in other types of information tools" (Leroyer 2011).

The above principles oppose the view of lexicography as a linguistic exercise, and therefore open the door for focusing on scientific endeavor to explain the process of decision-making in lexicography. In this paper, my interest lies in explaining the selection of Spanish equivalents in the Diccionario Inglés-Español de Contabilidad, one of the Accounting dictionaries that will briefly be presented in Section 3. Before this, however, Section 2 will review the concept of the specialized translation dictionary, as the Diccionario Inglés-Español de Contabilidad aims primarily to meet the needs of Spanish translators of English accounting texts. Section 4 constitutes the core of this paper, discussing the lexicographic rationale for taking real decisions on equivalent selection in specialized elexicography. This will help us to add support to our conviction regarding the necessity of upgrading theoretical discussions concerned with specialized lexicography. Finally, Section 5 will provide a summary of certain conclusions.

\section{Specialized Translation Dictionaries}

Specialized translation dictionaries are reference tools that aim to help users translate specialized texts. Dictionaries of this type are planned and compiled 
to assist the user in the transfer of a message from one language into another within a particular subject field (Fata 2010; Nielsen 2010).

Specialized translation dictionaries are usually planned and compiled with the aim of helping users disambiguate the meaning of the headword term by including linguistic, conceptual and pragmatic data, e.g., definitions, equivalents, synonyms, antonyms, usage labels, domain tags and illustrations. In some lexicographic traditions, e.g., in Spain, these dictionaries are usually identified as dictionaries that offer source language lemmas on the left and their target language equivalents on the right.

However, the value and usefulness of the traditionally-conceived bilingual specialized translation dictionary became open to question when functional approaches to translation and lexicography started to gain momentum. Translation scholars such as Nord (1997) shifted the focus of attention from terms and words to larger units, making a case for defending the iterative nature of the translation process with several recursive processes that go "beyond the levels of terms and words" (Nielsen 2010: 71), and defending a target-language orientation, by emphasizing that the "target-language texts must belong to the same genre as the source text and the linguistic and textual material that is borrowed must have the same pragmatic functions as those in the source text." (Nielsen 2010: 71).

The above situation coincided with the publication of a new generation of LSP dictionaries, which were the result of a function-based lexicographical approach initiated at the Centre for Lexicography (Aarhus School of Business) (Nielsen 1994). The authors defended the argument that specialized translation dictionaries should be more than a repository of terms and words, and proposed taking into consideration factors that are relevant in the translation process, most of which had hitherto been paid no attention by specialized lexicographers: text types and genres, use situation (for example, a translator of specialized texts also needs conceptual data), and culture. The Gene Technology Dictionary (Kaufmann, Bergenholtz, et al.) is an example of the then new approach. In its Preface (p. 7) it informs users that this dictionary is a polyfunctional tool which assumes that the user "possesses some familiarity with scientific language usage both in English and Spanish and a minimum of knowledge of biology and chemistry." More importantly, this specialized dictionary is very innovative, as it simultaneously performs the functions of an equivalence, explanatory and defining dictionary. For example, in a translation situation users benefit from three lexicographical developments in this dictionary:

- it contains an encyclopedic section, usually called a systematic introduction (Bergenholtz and Nielsen 2006), which explains the basics of gene technology and hence can be used when a professional translator, who is not an expert or semi-expert in gene technology, needs help in order to understand the basics of the domain; 
- the more central terms in the field are explained by means of translation equivalents and definitions, which help translators to place the term in its conceptual realm;

- it also contains some entries that "are included above all to help the user in a translation situation." (p. 8). For example, the inclusion of many multi-word expressions (e.g., anion exchange column) are relevant in a translation situation, considering that these expressions are difficult to translate and offer clues as to the degree of idiomaticity of the translated text.

In short, the functional approach to lexicography, as illustrated in the Gene Technology Dictionary, paved the way for planning and compiling specialized translation dictionaries that also included a comprehensive presentation of the subject field, lemmatized relevant multi-word expressions, and offered different, but complementary, ways of disambiguating meaning, especially in culture-dependent domains. These lexicographic decisions also permeate the planning and compiling of the Accounting dictionaries, as shown below.

3. The Accounting Dictionaries: The Diccionario Inglés-Español de Contabilidad

At an abstract level the relationship between lexicography and the Internet is mutually reinforcing, which lends support to the claims made on the inclusion of lexicography as part of Information Science (Leroyer 2011):

- Both lexicography and the Internet aim to provide quick and easy access to data from which users can retrieve the information needed in different types of social situations.

- The above aim is especially relevant in the current information and knowledge society, and hence both lexicography and the Internet contribute to this.

- Both lexicography and the Internet have to solve the problem of data suffocation, which occurs when users retrieve more data than needed.

- Both lexicography and the Internet target types of users in countless use situations, and not individual users in walled surroundings.

- Both lexicography and the Internet contain data that has been selected and prepared in the hope that potential users can convert this into information.

- Both lexicography and the Internet are currently analyzing options that will allow users to retrieve more focused hits. 
A critical examination of most existing Internet accounting dictionaries shows that the majority of them are a long way from compliance with the above relationship (Fuertes-Olivera and Nielsen 2011). This relationship assumes the validity of two very general principles. The first supports the idea that we do not need a new theory of lexicography at the highest level of abstraction (Gouws 2011; Tarp 2011); the second maintains that what we need is an adaptation of lexicography to the technical options of the Internet (Bothma 2011). Both principles translate into lexicographical discussions that agree on presenting the online dictionary and other types of lexicographic tools as utility products; such products must be planned and compiled afresh, with the aim of meeting users' needs in the light of new technologies made available to practical lexicography (see Fuertes-Olivera and Bergenholtz (2011) for a detailed discussion on theoretical assumptions regarding e-lexicography and some practical applications).

An exception to the dismal situation reported on in Fuertes-Olivera and Nielsen (2011) is the planning and compilation of the Accounting dictionaries. At present, they comprise a set of two monolingual and three bilingual online dictionaries using Danish, English and Spanish (a Spanish dictionary and a Spanish-English dictionary are in the pipeline). The theoretical foundation underlying the project gives priority to lexicographic functions, i.e., the assistance these dictionaries can give users in specific types of situation where they require knowledge to resolve issues relating to accounting (Bergenholtz and Tarp 2003, 2004; Nielsen and Mourier 2007; Tarp 2007 and 2008). The dictionaries are designed to meet certain types of user needs through the careful selection of data and specific options for data access, so that the answers to users' questions match their needs in a number of different contexts.

The Accounting dictionaries, which were originally developed at the Centre for Lexicography from 2002 onwards, can be divided into two different groups. On the one hand, those that deal with the English and Danish languages (Nielsen et al., 2010 and 2011) have been adapted to the practical and theoretical foundations of online lexicography "in light of the electronic options available to produce targeted reference tools and the advances described in the literature" (Nielsen and Almind 2011). This means that users can retrieve data depending on the function they select. For example, in one of the monolingual dictionaries they can elect to search for the following kinds of assistance:

- Help to understand an accounting term.

- Help to produce an accounting text where the expression is known.

- Help to find a term where the meaning is known.

- Show all data.

Tarp (2009: 57-58) illustrates the lexicographical options available in relation to text reception and text production. For example, if a Danish speaker reading an 
English text has a reception problem, the corresponding need for information may be provided in various ways depending on the characteristics of the reader. If the reader's proficiency level in terms of English accounting terminology and English language is high, then an English explanation would be sufficient in order to meet their needs. But if the reader's general and special English proficiency level is low, then their needs can only be satisfied by a Danish equivalent and/or explanation. Finally, if the proficiency level is more or less mid-way between the two former, then a combination of Danish and English would be the best way to ensure that the needs are met.

On the other hand, the accounting dictionary that deals with Spanish, $E l$ Diccionario Inglés-Español de Contabilidad, is only equipped with a kind of 'show all function', and consequently users retrieve all the data contained in the dictionary article they consult.

Examples (1), (2) and (3) illustrate the differences between the two groups of Accounting dictionaries. A user who consults deemed cost in the English Accounting Dictionary obtains example (1) when they elect to choose 'help to understand an accounting term', example (2) when they choose 'help to produce accounting texts where the expression is known', whereas they retrieve example (3) when consulting El Diccionario Inglés-Español de Contabilidad:

(1) Definition as help to understand an accounting term

deemed cost $<a$, the, $-\mathrm{s}>$

Definition

Deemed cost is an amount used instead of cost or depreciated cost at a specific date. Any following amortisation or depreciation is made on the assumption that the enterprise initially recognised the asset or liability at a cost equal to the deemed cost.

(2) Data presented to give help to produce accounting texts where the expression is known

deemed cost $<\mathrm{a}$, the, $-\mathrm{s}>$

\section{Definition}

Deemed cost is an amount used instead of cost or depreciated cost at a specific date. Any following amortisation or depreciation is made on the assumption that the enterprise initially recognised the asset or liability at a cost equal to the deemed cost.

\section{Collocations}

fair value or revaluation as deemed cost

have a deemed cost of zero in the opening IFRS balance sheet

the deemed cost of goodwill

use an event-driven fair value measurement as deemed cost

Examples

Items of property, plant and equipment are measured at cost as deemed cost less accumulated depreciation and impairment losses. 
(3) Data presented when the search word is deemed cost

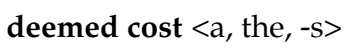

Deemed cost is an amount used instead of cost or depreciated cost at a specific date. Any following amortisation or depreciation is made on the assumption that the enterprise initially recognised the asset or liability at a cost equal to the deemed cost.

coste atribuido

synonyms

coste asignado

collocations

- fair value or revaluation as deemed cost valor razonable o revalorización como coste atribuido

- have a deemed cost of zero in the opening IFRS balance sheet tener cero como coste atribuido en el balance de apertura basado en la NIIF

- the deemed cost of goodwill el coste atribuido del fondo de comercio

- use an event-driven fair value measurement as deemed cost utilizar una medición del valor razonable de un acontecimiento inevitable como coste atribuido

examples

- Items of property, plant and equipment are measured at cost as deemed cost less accumulated depreciation and impairment losses.

Las partidas de edificios, instalaciones y equipos se valoran al coste como coste atribuido menos amortización acumulada y deterioros.

sources

IFRS1, Appendix A

Briefly, the data retrieved has been tailored to the user's needs in the use situation when they consult the English Accounting Dictionary, whereas this option is not yet available in the Dicconario Inglés-Español de Contabilidad. This EnglishSpanish dictionary is a polyfunctional dictionary that helps to read and understand and produce accounting texts, translate English accounting texts into Spanish, and acquire knowledge about accounting matters. In other words, the Diccionario Inglés-Español de Contabilidad does not yet benefit "from an overall and more stringent functional approach where the corresponding search mechanisms may lead their users to dynamic data (articles) that are especially adapted to each and every of the various types of users and situations covered by the dictionary in question." (Tarp 2009: 57-58).

With the aim of minimizing the risks associated with retrieving static data, the Diccionario Inglés-Español de Contabilidad has incorporated functions which are not usually found in other Internet accounting dictionaries. For example, it includes the search option contains, with which users can retrieve all the articles in which the search word is part of the word list. A search for the term account- 
ing with contains in the scroll menu retrieves 92 articles. The short definition given in each article, as well as the data included in the article, allows users to gain some fundamental knowledge about this key accounting concept (FuertesOlivera and Tarp 2011). In addition, the lexicographers also adopted decisions that can be explained from a user-oriented lexicographic approach. For instance, the decisions concerning the selection of Spanish equivalents, which are discussed below, can be explained in a lexicographic way and are based on the characteristics of LSP lexicography.

\section{A Case Study: Selecting Spanish Equivalents for English Accounting Terms in the Diccionario Inglés-Español de Contabilidad}

As a research methodology, case study research has been extremely influential in shaping the way we do research in the Social Sciences (Casanave 2010). For example, in the field of education, Wolcott's study on general education (1973), Halliday's study of Nigel's first language acquisition (1975), and Schmidt's study in second language learning (1983) can be cited, as they "have shaped discussion and research in their respective fields of focus in forceful and productive ways." (Van Lier 2005: 195).

Case study research is a contextual type of investigation that has three main characteristics (Casanave 2010). First, its object of inquiry is unique and delimited, i.e., bounded. This means that the researcher's interest is in the particular rather than the general. In other words, a case study investigates one person, one group, one institution, one community, or a particular bounded phenomenon. Secondly, by choosing a case study tradition, researchers are committed to presenting in-depth analyses of particular phenomena, be they particular people, sites, groups, institutions, dictionary articles, teaching materials, etc. Thirdly, case studies are always situated or embedded in a particular context (Yin 2003).

The case study reported on in this paper is concerned with the selection of equivalents in the specialized Internet dictionary El Diccionario Inglés-Español de Contabilidad. Instead of focusing on quantitative methods, the case is delimited to explaining in detail the rationale for the decisions taken in the framework of functional approaches to specialized lexicography. Such decisions not only hypothesize the adequacy of deductive methodologies but also conclude that lexicographers' decisions must first of all be discussed in terms of the function(s) the dictionary aims to solve in specific use situations where users' needs can be met; secondly, they should be situated in the area of specialized language, whose characteristics and defining properties make it different from general language.

A review of the literature that examines equivalence shows that most researchers explain the concept of equivalence in terms of the abstract value it has in the system and its concrete presence in the text (i.e., interlingual or intertextual equivalence), as well as its corollary of full equivalence, partial equiva- 
lence, and zero equivalence (Pedersen in Bergenholtz and Tarp 1995: 104-110; Fuertes-Olivera and Arribas-Baño 2008: 88-90; Adamska-Sałaciak 2010: 387409). This research examines equivalence in connection with bilingual lexicography, although researchers do not ignore the fact that the presence of translation equivalents does not make the dictionary bilingual (Gouws 2004), nor that all 'so-called' bilingual dictionaries can be used for translation (Tarp 2005). Nkomo (2008: 132) is right when he says that we have "to dispel some erroneous beliefs which result in dictionaries which provide translation equivalents as data categories being misused and hence unfairly evaluated."

Adamska-Sałaciak (2010), for example, examines equivalence as an interdisciplinary concept, and defends an explanation of the concept of equivalence by looking outside lexicography, i.e., in the area of disciplines such as contrastive linguistics and translation. Regarding contrastive linguistics, she claims that it is convenient to distinguish two stages in the explanation offered, and adds that lexicographers can mostly benefit from the second stage, which appeared with the advent of electronic corpora. In particular, she urges the use of comparable and/or parallel corpora for extracting interlingual correspondences as an appropriate methodology for solving the practical problem of selecting an equivalent in lexicography. Regarding translation, she accepts Halverson's (1999 and 2002) suggestion that translation be viewed as a prototype concept that allows us to understand equivalence as "a broad spectrum of relations, from similarity to identity." (Adamska-Sałaciak 2010: 403).

My view of specialized lexicography is rather different. I agree with her that electronic collections of texts can offer clues as to which equivalent must be selected. However, this is a practical activity that cannot be translated into offering a theoretical examination of the decisions taken in a real specialized lexicography project. For instance, corpora inform researchers about frequency but not about relevance, and they illustrate the existence of variation. Both issues, frequency and variation, run contrary to the nature of specialized communication. Similarly, prototypical equivalence is not adequate in specialized communication, in which, given that redundancy, widespread in general language, is typically avoided in specialized language, only full equivalence is a solution. For example, supposing we are dealing with an English International Accounting Standard (IAS) concept, we have to offer the exact full Spanish equivalent and not a proxy which could confuse investors, who might then ask for compensation if this confusion cost them money.

For specialized dictionaries, the concept of equivalence has to be addressed in lexicographical terms, and this implies taking into consideration the intended user of the dictionary, the intended use situation, the intended function(s) and the nature of specialized communication, especially when the subject domain can be described as culture-dependent (Mheta and Muhwati 2009). For example, if the dictionary aims primarily at meeting a user's needs when reading a text, the inclusion of an explanatory equivalent or a translational equivalent is more or less irrelevant. However, if the dictionary's main aim is to 
meet the needs a user has when translating a text, it is very important to include a translational equivalent instead of, say, an explanatory one. Similarly, if the dictionary is concerned with producing texts, then the inclusion of synonyms is appreciated by the intended user, who will regard them as suitable equivalents and useful lexicographic structures in the communicative situation associated with text production.

The process of equivalent selection in LSP lexicography needs a lexicographic explanation that initially contemplates the true nature of lexicography as well as that of LSP communication in today's world. Contrary to what occurs in general lexicography, where new words and meanings need time to become standardized and accepted (usually because redundancy is widespread and meaning fluctuates before standardization), terms are accepted from the outset, and are then coined and adapted by experts; the latter then give these terms an unambiguous denomination, using them in professional genres and registers before they are noticed by terminology standardization committees and professional and/or amateur lexicographers. This implies adopting an approach to equivalent selection that acknowledges, first of all, experts' tendency to coin and use terms before they are sanctioned by terminological committees; secondly, that terms in widespread use cannot be eliminated; and, thirdly, that term formation in languages such as Spanish is very much influenced by economic reasons and the spread of English as the lingua franca of LSP communication. This occurs especially when dealing with disputed terms, as shown below.

Economic reasons are manifest in the fact that modern technology is based on the principle of the division of work, and that it does not function without verbal communication (Teubert 2005). This has brought to the fore the fact that terminology is also a commercial activity, with many companies paying large sums for acquiring multilingual terminologies that describe the products they sell, establishing their own terminology departments, and fighting to create, develop and standardize "the LSP they use themselves and want to force their competitors to use." (Teubert 2005: 97).

It is not only that technology rules our modern world, but that this technology is no longer self-explanatory. It needs instructions, leaflets for describing the product, the installation procedures, etc. In short, modern technology needs to improve communication strategies by which a given term denotes the same concept for producer (or developer) and user.

The spread of English in LSP communication, which is associated with economic globalization, is also making a deep impact on specialized lexicography. For example, it is blurring the difference between culture-dependent and culture-independent domains, as will be shown below when I explain the selection of International Accounting Standard/International Financial Reporting Standard (IAS/IFRS) terms in Spanish.

This general framework has influenced the process of equivalent selection in the Diccionario Inglés-Español de Contabilidad, which comprises both the selection of a proper equivalent and its synonym (where necessary), and which can 
be explained as the result of three lexicographical principles that have permeated our lexicographic project: relevance, proscription and recreation. For the sake of simplicity, I will restrict the explanation to decisions taken when lexicographers face several possibilities, i.e., when equivalents are disputed and lexicographers cannot find a standardized full Spanish equivalent.

Fuertes-Olivera and Nielsen (2011) claim that the principle of relevance refers to the quality of being directly connected with the subject field in question, the function(s) of the dictionary, and the situation in which the dictionary is intended to be used. As the Diccionario Inglés-Español de Contabilidad is primarily directed at assisting Spanish translators of English accounting texts, the principle of relevance requires the selection of an insertable equivalent, whatever this may be called. Hence, in the Diccionario Inglés-Español de Contabilidad, there is always one, and only one, insertable equivalent per English lemma (see Example 3, above). This decision, which is based on the tenets of the function theory of lexicography (Bergenholtz and Tarp 2003 and 2004), follows Nielsen et al.'s practice in their planning and compilation of the Accounting dictionaries in Danish and English (2010 and 2011). Moreover, this practice agrees with the principle maintaining that more choices do not necessarily lead to greater customer satisfaction, and is a kind of 'proxy' device which is intended to eliminate the stress users suffer when a search retrieves much more data than needed (the so-called 'Google suffocation effect').

By including only one equivalent per lemma, the dictionary helps translators to use the right translation equivalent. For example, the English term "balance" has four dictionary articles, and therefore, four Spanish equivalents: balance, saldo, deuda and saldar. This practice constitutes a novelty in Spanish specialized lexicography, which is characterized by bilingual dictionaries that include as many equivalents as possible, usually without disambiguating them properly, as example (4) shows:

(4) The entry "balance" in the Diccionario Técnico Económico-Financiero-Actuarial. Inglés-Español (Villalón and Martínez Barbeito 2008)

Balance: Saldo, diferencia. Balanza, equilibrio. Balance, resto.

The principle of relevance also explains the fact that lexicographers must opt for a one-to-one equivalence in specialized lexicography. Contrary to what has been claimed in general lexicography in the context of bilingualized lexicography, users of specialized dictionaries need lexicographic structures that offer them very precise meaning, not only because this is connected with the very nature of specialized discourse, but also because redundancy tends to be absent from specialized texts. In specialized lexicography users require meaning, therefore, to be precise. In the Accounting dictionaries this was achieved by also including a Cobuild-style definition per lemma. Hence, the inclusion of an English definition and a Spanish insertable equivalent makes the Diccionario Inglés-Español de Contabilidad a novelty in Spanish specialized lexicography, 
offering an innovative lexicographic solution with which users can eliminate the problems associated with homonymy and polysemy in specialized texts. Furthermore, as users of specialized texts need lexicographic structures that make meaning very precise and unambiguous, this dictionary also has a wellconceived lexicographic layout that facilitates the disambiguation of homonymous and polysemous terms. These are differentiated by means of superscripts and Arabic numbers, respectively. In Figure 1 the superscripts ${ }^{1}$ and ${ }^{2}$ indicate that balance can be a noun or a verb, whereas the Arabic numbers 1 and 2 indicate that as a noun "balance" has two different meanings.

balance ${ }^{1}$

$<$ noun a, the, - s $>$

balance

1

\section{definition}

A balance is the net amount or amount remaining after part has been taken away, i.e. the difference between debits and credits in an account.

saldo

collocations

- a balance not written down

un saldo no amortizado

- the balance of accumulated profit or loss at the beginning of the period el saldo de la cuenta de pérdidas y ganancias a principios del periodo example

- The account showed a positive balance of $£ 350$.

La cuenta mostraba un saldo positivo de 350 libras.

synonyms

account balance

2

\section{definition}

A balance is an amount owed, i.e. an outstanding debt payable.

deuda

collocations

- a comprehensive analysis of related party balances

un análisis global de las deudas de las partes implicadas

- balances in foreign currencies

balance 2

$<$ verb -s, $-\mathrm{d}$, has $-\mathrm{d}$, balancing $>$

definition

To balance means to reconcile the debit and the credit side of an account to determine the balance.

saldar

collocations

balance off

saldar

Figure 1: Excerpt from El Diccionario Inglés-Español de Contabilidad 
The inclusion of only one insertable Spanish equivalent connects the process of equivalent selection with the choice of descriptive, prescriptive, and proscriptive lexicography; these three key lexicographic concepts have been analyzed by Bergenholtz (2003), and Bergenholtz and Gouws (2010), with the aim of making them precise in a lexicographic sense. Considering the dictionary as a practical tool implies that the terms descriptive, prescriptive and proscriptive cannot be applied to the whole dictionary but to the lexicographic processes present in the planning and compiling of every dictionary article. In other words, when a lexicographer uses data from a linguistic survey and a text investigation in their practical lexicographic work, the process is an example of descriptive lexicography (Bergenholtz 2003); the same lexicographer is using a prescriptive approach when they state that a specific linguistic variant is explicitly prohibited, or that one or more linguistic variants are explicitly prescribed (Bergenholtz 2003); finally, the lexicographer is using a proscriptive approach when they (explicitly) recommend a variant and their recommendation is based on an in-depth analysis of the several options available (Bergenholtz 2003) (see Bergenholtz and Gouws 2010 for a detailed lexicographic discussion of the different types of prescription, description and proscription identified so far).

The proscriptive approach is extremely important when planning and compiling a specialized translation dictionary, especially in three specific lexicographic situations which oblige lexicographers to face a hard choice: (i) when a new concept is introduced, (ii) when there is variation among terms, and (iii) when the linguistic structure of a language does not favour the translation of the lemma in a new language (for example, the translation of English -ing terms into Spanish is always difficult, and sometimes impossible). This could be an example of what Bergenholtz and Gouws (2010: 38) identify as a choice among descriptive, prescriptive and proscriptive lexicography, which has to be solved by resorting to a "language and communication policy decision". In such a situation the proscriptive approach means that lexicographers offer an insertable equivalent. Their decision is mostly conditioned by the nature of LSP communication, especially the necessity of having a one-to-one correspondence between a concept and its linguistic representation, which makes it necessary for lexicographers to include full equivalents in the lexicographic tools they plan and compile.

A case in point occurs when Spanish lexicographers are forced to decide on the various Spanish accounting terms that correspond to the English IAS/IFRS terms. The IASs and IFRSs (International Accounting Standards and International Financial Reporting Standards, respectively) are examples of equal texts, i.e., texts that have been prepared in a language (usually English) and then translated into the different official languages of an organization such as the European Union. Equal texts conceptualize (new) realities that have been identified in the Accounting dictionaries as IAS/IFRS terms. These terms are widespread in accounting (In the Diccionario Inglés-Español de Contabilidad there are 377 English IAS/IFRS terms.) and are used in order to refer to normalized and standardized concepts, i.e., concepts that were defined by the writers of the 
above-mentioned standards and are, therefore, obligatory when preparing official accounting documents. In other words, accountants must use these IAS/ IFRS terms whenever they draw up accounting documents.

It may happen that translators of these equal texts do not know that a particular concept already has a well-known established Spanish term, or they may commit a translation mistake, which can easily lead to a conceptual mistake. Both situations occur with the Spanish IAS/IFRS terms. Examples of nonsensical Spanish renderings were found, as well as the introduction of unnecessary Spanish terms, i.e., the translators of the IAS/IFRS rules were unaware of the existing Spanish term and introduced a new one in the Spanish International Accounting Standards/International Financial Reporting Standards.

Both problems were resolved in the Diccionario Inglés-Español de Contabilidad by the inclusion of lexicographic notes (e.g., "Spanish accountants prefer resultado de explotación to the IAS/IFRS term resultado operativo"; or "the IAS/ IFRS term is nonsensical in Spanish"), and by making frequent use of exact proscription, the term by means of which Bergenholtz and Gouws (2010) refer to the process of recommending one equivalent, although other equivalents may be mentioned. This resulted in the selection of traditional Spanish equivalents (for instance: cuenta deudora; beneficio contable; producción agrícola; valor contable; tesorería; clasificado por tipo de gasto; etc.) and the inclusion of the Spanish translated IAS/IFRS terms as synonyms (cuenta a cobrar; ganancia contable; producto agrícola; valor en libros; efectivo; clasificado por naturaleza; etc.)

Finally, the concept of recreation was used in El Diccionario Inglés-Español de Contabilidad. Recreation refers to the process of creating a Spanish equivalent whenever it is deemed necessary, either because there were fluctuations (variations) between competing terms, or because the existing Spanish term was not always insertable, perhaps because it could lead to misunderstanding due to the existence of different accounting traditions. The accounting experts who took part in the process of selecting Spanish equivalents referred to the necessity of using the process of recreation in two specific use situations, which are analyzed below.

The first one occurs when Spanish accountants typically use the English terms, usually as superordinates. A typical example occurs with "rating". Although traditionally-conceived English-Spanish dictionaries of business/economics include calificación crediticia, and calificación de solvencia as equivalents of English "rating", rating was maintained as the Spanish equivalent, and calificación crediticia and calificación de solvencia were included as synonyms.

The above decision is justified in terms of the external and internal subject classification made for selecting equivalents: this showed that calificación crediticia and calificación de solvencia could also be used in order to refer to the creditworthiness of a person, something that does not happen with "rating", which always refers to the creditworthiness of a country and/or organization. This difference is important in specialized lexicography, and could lead to misun- 
derstandings if they were selected as equivalents. In other words, calificación crediticia and calificación de solvencia are not always full equivalents of English "rating", and might as a result lead to confusion and misunderstanding among users.

This problem disappears, however, if they are selected as synonyms, as this decision informs users that the terms are restricted to the exact meaning of "rating", and that they can be conveniently used when the text is unambiguous so as to comply with academic traditions requiring the use of synonyms in formal Spanish texts. To sum up, the lexicographers selected rating as equivalent because this term always shows full equivalence, whereas calificación crediticia and calificación de solvencia were selected as synonyms because both can also be used in other domains where they are no equivalents of English "rating".

The second situation involved selecting literal renderings of English terms as Spanish equivalents. This process was used whenever a literal translation was found that could be understood by Spanish speakers. The frequent use of recreation in this situation can be explained by referring to the status of English as the lingua franca of specialized communication, and by resorting to explanations based on the translation agent model, which aims to offer clues as to the cognitive processes undertaken by translators when translating (Chesterman 2009; Fuertes-Olivera submitted).

Lexicographers used to maintain that politics, economics and law are examples of culturally-dependent areas: they have developed their own specific features within a delimited geographical area. They also added that although a clear-cut distinction between culture-dependent and culture-independent domains cannot always be made, this problem had been solved by including partial equivalents and/or paraphrases rather than true equivalents. For example, some traditionally-conceived business/economics English-Spanish dictionaries, e.g., the Diccionario Técnico Económico-Financiero-Actuarial (Villalón and Martínez Barbeito 2008), often use paraphrase instead of a translation equivalent, as observed in example (5):

(5) Commodity pool: Un fondo de productos que confía los fondos de muchos inversores a un fondo professional de negociación y distribuye beneficios y pérdidas entre los participantes en proporción a sus intereses.

The above solutions are not appropriate in a translation dictionary: paraphrases are not insertable, and, moreover, partial equivalents can mislead users, as revealed in the discussion on rating. Instead, literal translations were produced, since this is what is typically done when experts come across an English term for the first time. This assumption agrees with the nature of specialized communication, i.e., with the necessity of finding a one-to-one correspondence between concept and term. Hence, it was deemed appropriate for specialized lexicography and consequently adopted, especially because this practice coincides with certain conclusions drawn in several empirical studies 
showing that translators of specialized texts disambiguate and reproduce meaning more easily when the terms in the source and target language are conceptually related; this, for instance, occurs when they belong to the same conceptual scenario (Fuertes-Olivera and Nielsen 2011). This is particularly the case with multi-word terms, such as business combination involving entities or businesses under common control. For this English lemma the lexicographers selected the Spanish literal translation, combinación de negocios entre entidades o negocios bajo control común, as equivalents. In fact, such a decision is of considerable importance in this dictionary, considering that the number of lemmata similar to business combination involving entities or businesses under common control is quite large. For example, terms for accounting accounts, sub-accounts, classifications, sub-classifications, etc., reported in an accounting document, e.g., an income statement (see Table 1), were included as lemmas; these are conceptually and communicatively necessary. Table 1 shows the conceptual categories of an Income Statement by Nature in English and Spanish:

\begin{tabular}{|c|c|}
\hline Income Statement by nature & $\begin{array}{l}\text { Cuenta de resultados (cuenta de pérdidas y } \\
\text { ganancias) por naturaleza }\end{array}$ \\
\hline 1. Continuing operations (where appropriate) & 1. Operaciones continuadas (si es adecuado) \\
\hline 2. Revenue (Sales) & 2. Ingresos por ventas \\
\hline 3. Other operating income & 3. Otros ingresos de explotación \\
\hline $\begin{array}{l}\text { 4. Changes in inventories of finished goods } \\
\text { and work in progress }\end{array}$ & $\begin{array}{l}\text { 4. Variaciones de existencias de productos } \\
\text { terminados y en curso de fabricación }\end{array}$ \\
\hline $\begin{array}{l}\text { 5. Work performed by the company and } \\
\text { capitalised }\end{array}$ & $\begin{array}{l}\text { 5. Trabajos realizados por la empresa para } \\
\text { su activo }\end{array}$ \\
\hline 6. Raw materials and consumables & 6. Materias primas y consumibles \\
\hline 7. Employee benefits expense & 7. Gastos de personal \\
\hline 8. Other operating expenses & 8. Otros gastos de explotación \\
\hline $\begin{array}{l}\text { 9. Earnings before Interest, Tax, Deprecia- } \\
\text { tion and Amortisation (EBITDA) }\end{array}$ & $\begin{array}{l}\text { 9. Resultado antes de intereses, impuestos } \\
\text { y amortizaciones (EBITDA) }\end{array}$ \\
\hline 10. Depreciation expense & 10. Gasto por depreciación \\
\hline $\begin{array}{l}\text { 11. Impairment of property, plant and } \\
\text { equipment }\end{array}$ & 11. Deterioro del inmovilizado \\
\hline $\begin{array}{l}\text { 12. Earnings before Interest, Tax and } \\
\text { Amortisation (EBITDA) }\end{array}$ & $\begin{array}{l}\text { 12. Resultado antes de intereses, impuestos y } \\
\text { amortizaciones (EBITDA) }\end{array}$ \\
\hline 13. Amortisatio & 13. Gasto por amortizaciones \\
\hline 14. Impairment of goodwill & 14. Deterioro del fondo de comercio \\
\hline $\begin{array}{l}\text { 15. Earnings before Interest and Taxes } \\
\text { (EBIT) }\end{array}$ & $\begin{array}{l}\text { 15. Resultado antes de intereses e impuestos } \\
\text { (EBIT) }\end{array}$ \\
\hline 16. Finance costs, net & 16. Gastos financieros netos \\
\hline 17. Share of profit of associates after tax & $\begin{array}{l}\text { 17. Participación en beneficios en asociadas } \\
\text { después de impuestos }\end{array}$ \\
\hline 18. Profit before tax & 18. Resultado antes de impuestos \\
\hline 19. Income tax expense & 19. Impuestos sobre beneficios \\
\hline 20. Profit for the period & 20. Resultado del ejercicio \\
\hline Where appropriate distributed into: & Distribuido si es apropiado entre: \\
\hline $\begin{array}{l}\text { 21. Profit for the period from continuing } \\
\text { operations }\end{array}$ & $\begin{array}{l}\text { 21. Resultado del ejercicio procedente de } \\
\text { operaciones continuadas }\end{array}$ \\
\hline 22. Discontinued operations & 22. Operaciones interrumpidas \\
\hline
\end{tabular}




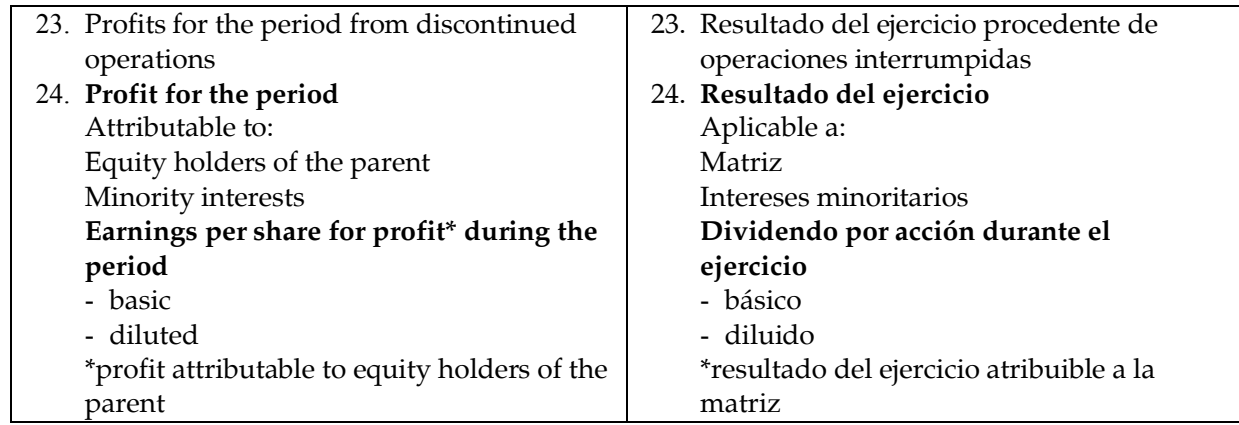

Table 1: The Income Statement by Nature in the Diccionario Inglés-Español de Contabilidad.

An analysis of Table 1 illustrates the rationale for the decisions taken when selecting the Spanish equivalents, which have been previously discussed and are summarized below. First, some of the equivalents are traditional Spanish equivalent terms that do not impose any burden on the lexicographer. These are bound to be encountered in real texts. They were found by means of an internal and external subject classification, as well as by the web being used as a corpus. For example, a consultation of official and relevant accounting texts, such as a Spanish cuenta de resultado and an English income statement or profit and loss account, offers clues about suitable standardized equivalents.

Secondly, some of the equivalents, for example, cuenta de resultados and cuenta de pérdidas y ganancias, fluctuate in Spanish: the former is the Spanish traditional term, whereas the latter is a literal translation that entered into Spanish through a translation. On such occasions the lexicographers selected the Spanish traditional term as an equivalent and the translated term as a synonym.

Thirdly, in some cases the original English term is adopted, i.e., as a borrowing from English, e.g., EBITDA. In these situations a Spanish term is usually included as a synonym, especially when the Spanish term is not an example of full equivalence. For instance, English accountants differentiate between depreciation and amortization, a differentiation that does not occur in Spanish traditional accounting texts, where the term amortizaciones is the only one used for both depreciation and amortization. As these two English terms differ slightly, using EBITDA as a Spanish equivalent minimizes the possibility of misunderstanding.

Fourthly, some of the Spanish equivalents are translations, usually literal ones, of English lemmas. For instance variaciones de existencias de productos terminados y en curso de fabricación is the Spanish translation of English changes in inventories of finished goods and work in progress.

\section{Conclusion}

This paper deals with specialized e-lexicography and maintains the necessity of 
using a lexicographic approach for explaining the decisions taken when planning and compiling specialized dictionaries. Without disputing the (possible) advantages of the methods and procedures that are currently being used in general lexicography, this paper defends the view that LSP e-lexicography needs its own methods and practices, which take into consideration the nature of specialized communication and the technical options the Internet offers, and uses them within the tenets of a user-based approach, e.g., the function theory of lexicography.

The above idea is illustrated by an explanation of some of the decisions taken when selecting Spanish equivalents for the Diccionario Inglés, Español de Contabilidad, one of the Accounting dictionaries; these are a set of Internet specialized dictionaries that aim at satisfying the needs of translators (primary user group), accountants and financial experts (secondary user group), as well as students of accountancy and translation, journalists and interested laypersons (tertiary user group).

In particular, this paper elaborates on decisions concerned with selecting equivalents that are not yet well established, i.e., those that must refer to original English accounting terms, and which pose a lexicographic problem because they are new, difficult to translate, or fluctuate among several options. In such situations, we have explained the decisions as a result of three lexicographic principles that offer a rationale for most of the ones made in the dictionary here discussed: relevance, proscription, and recreation. The workings of these three principles and their rationale are explained as a case study, which implies a contextual form of research that is confined to an in-depth analysis of a bounded phenomenon; this was illustrated with a selection of dictionary entries revealing the workings of the three principles underlying lexicography that lend support to a lexicographic approach to terminology.

In conclusion, our exercise, i.e., the theoretical foundations on which fluctuating equivalents were selected, reinforces the condition of lexicography as a scientific endeavour. In this regard, it illustrates that equivalents were selected as a result of in-depth analyses of the nature of LSP lexicography and specialized communication, in addition to well-attested theoretical lexicographic considerations advocating the designing of specialized dictionaries planned and compiled to assist specific users to solve their information needs in specific use situations. Unfortunately, there are still many practitioners who continue planning and compiling dictionaries without taking into consideration the above reflections. This is what we typically found in traditional specialized translation dictionaries published in Spain (for example, the Diccionario Técnico). At best, such a dictionary is only useful for confirming the user's conjecture. It is to be hoped that the future of specialized lexicography, especially in places such as Spain, will reside in lexicographic principles and practices that are based on critical thinking and not on traditions, methods and practices taken for granted. This view is also shared by lexicographers at the Centre for Lexicography, who are now working with a new conceptual scenario: the building of lexicographic 
data banks, usually called lexicographic databases, which are different from information tools. We should no longer view language as the main argument for classifying dictionaries, but rather the functions. Regarding the Accounting dictionaries, we have a single accounting database (Nielsen and Almind 2011), which can feed 23 totally monofunctional specialized e-dictionaries of accounting (Bergenholtz forthcoming): 13 of them (numbers 1 to 13 below), which have been prepared by Nielsen, Mourier, Bergenholtz and Almind (2011), are already in operation. The rest will be so in the near future:

\section{Danish}

1. Meaning of Danish accounting terms.

2. Use of Danish accounting terms, search with a known term.

3. Use of Danish accounting terms, search based on a known meaning.

4. Knowledge of Danish accounting terms, search with a known term.

\section{English}

5. Meaning of English accounting terms.

6. Use of English accounting terms, search with a known term.

7. Use of English accounting terms, search based on a known meaning.

8. Knowledge of English accounting terms, search with a known term.

\section{English-Danish}

9. Reception of English terms in English accounting texts.

10. Translation of English accounting texts into Danish.

11. Knowledge of English and Danish accounting terms.

\section{Danish-English}

12. Translation of Danish accounting texts into English.

13. Knowledge of English and Danish accounting terms.

\section{Spanish}

14. Meaning of Spanish accounting terms.

15. Use of Spanish accounting terms, search with a known term.

16. Use of Spanish accounting terms, search based on a known meaning.

17. Knowledge of Spanish accounting terms, search with a known term. 


\section{Spanish-English}

18. Reception of English terms in English accounting texts.

19. Translation of Spanish accounting texts into English.

20. Knowledge of Spanish and English accounting terms.

\section{English-Spanish}

21. Reception of English terms in English accounting texts.

22. Translation of English accounting texts into Spanish.

23. Knowledge of English and Spanish accounting terms.

\section{Acknowledgments}

Thanks are due to Ministerio de Ciencia e Innovación (grant FFI200801703/FILO) and Junta de Castilla y León (grant VA039A09) for financial support. Thanks also go to Henning Bergenholtz for his comments on a draft of this paper. I myself am responsible for any remaining mistakes.

\section{References}

\section{Dictionaries}

Kaufmann, U., H. Bergenholtz in cooperation with B. Stummann, S. Tarp, L. de la Rosa Marabet, G. la Serna Miranda and N. la Serna Torres. 1998. Encyclopedic Dictionary of Gene Technology. Volume I. English (with Spanish Equivalents). Toronto: Lugus.

Nielsen, Sandro, Lise Mourier, Henning Bergenholtz, Pedro A. Fuertes-Olivera, Pablo Gordo Gómez, Marta Niño Amo, Angel de los Rios Rodicio, Angeles Sastre Ruano, Sven Tarp and Marisol Velasco Sacristán. 2009. El Diccionario Inglés-Español de Contabilidad. Available at: http://www.accountingdictionary.dk/regn/gbsp/regngbsp_index.php [01/09/2011]

Nielsen, S., L. Mourier and H. Bergenholtz. 2010. Database and Design: R. Almind. Danish Accounting Dictionary; Danish-English Accounting Dictionary; English Accounting Dictionary; English-Danish Accounting Dictionary. URL: http://www.ordbogen.com/ordboger/regn/index.php?dict=a007. (Last accessed 20 January 2011.)

Nielsen, S., L. Mourier and H. Bergenholtz. 2011. Database and Design: R. Almind. Meaning of Danish Accounting Terms. Use of Danish Accounting Terms, Search with a Known Term. Use of Danish Accounting Terms, Search with a Known Meaning. Knowledge about Danish Accounting Terms, Search with a Known Term. Meaning of English Accounting Terms. Use of English Accounting Terms, Search with a Known Term. Use of English Accounting Terms, Search with a Known Meaning. Knowledge of English Accounting Terms, Search with a Known Term. Reception of English Terms in English Accounting Texts. Translation of English Accounting Texts. Knowledge about English-Danish Accounting. Translation of Danish Accounting Texts. Knowledge about Danish-English Accounting. http://www.Ordbogen.com. 
Villalón, J.G. and J. Martinez Barbeito. 2008. Diccionario Técnico. Económico-Financiero-Actuarial. Inglés-Español. Valladolid: Universidad de Valladolid.

\section{Other Literature}

Adamska-Sałaciak, A. 2010. Examining Equivalence. International Journal of Lexicography 23(4): 387409.

Andersen, B. and R. Almind. 2011. The Technical Realization of Three Monofunctional Phrasal Verb Dictionaries. Fuertes-Olivera, P.A. and H. Bergenholtz (Eds.). 2011. e-Lexicography. The Internet, Digital Initiatives and Lexicography: 208-229. London/New York: Continuum.

Barnbrook, G., P. Danielsson and M. Mahlberg (Eds.). 2005. Meaningful Texts: The Extraction of Semantic Information from Monolingual and Multilingual Corpora. London/New York: Continuum. [Research in Corpus and Discourse.]

Bergenholtz, H. 2003. User-oriented Understanding of Descriptive, Proscriptive and Prescriptive Lexicography. Lexikos 13: 65-80.

Bergenholtz, H. Forthcoming. Concepts for Monofunctional Accounting Dictionaries. Terminology 18.

Bergenholtz, H. In press: Do We Need Another Theory of Lexicography? Lexicon 41.

Bergenholtz, H. and Rufus H. Gouws. 2010. A Functional Approach to the Choice between Descriptive, Prescriptive and Proscriptive Lexicography. Lexikos 20: 26-51.

Bergenholtz, H. and S. Nielsen. 2006. Subject-field Components as Integrated Parts of LSP Dictionaries. Terminology 12(2): 281-303.

Bergenholtz, H. and S. Tarp (Eds.). 1995. Manual of Specialised Lexicography. Amsterdam/Philadelphia: John Benjamins. (Benjamins Translation Library 12.)

Bergenholtz, H. and S. Tarp. 2003. Two Opposing Theories: On H.E. Wiegand's Recent Discovery of Lexicographic Functions. Hermes. Journal of Linguistics 31: 171-196.

Bergenholtz, H. and S. Tarp. 2004. The Concept of Dictionary Usage. Nordic Journal of English Studies 3: 23-36.

Bergenholtz, H., S. Nielsen and S. Tarp (Eds.). 2009. Lexicography at a Crossroad: Dictionaries and Encyclopedias Today, Lexicographica Tools Tomorrow. Bern/Berlin/Bruxelles/Frankfurt am Main/New York/Oxford/Wien: Peter Lang. (Studies in Language and Communication 90.)

Bothma, T. 2011. Filtering and Adapting Data and Information in an Online Environment in Response to User Needs. Fuertes-Olivera, P.A. and H. Bergenholtz (Eds.). 2011. e-Lexicography. The Internet, Digital Initiatives and Lexicography: 71-102. London/New York: Continuum.

Casanave, C. 2010. Case Studies. Paltridge, B. and A. Phakiti (Eds.). 2010: 66-79.

Chesterman, A. 2009. The Name and Nature of Translator Studies. Hermes. Journal of Language and Communication Studies 42: 13-22.

Fatá, I. 2010. The Bilingual Specialised Translation Dictionary for Learners. Fuertes-Olivera, Pedro A. (Ed.). 2010. Specialised Dictionaries for Learners: 83-106. Berlin/New York: De Gruyter.

Fuertes-Olivera, Pedro A. 2009. Systematic Introductions in Specialised Dictionaries: Some Proposals in Relation with the Accounting Dictionaries. Nielsen, Sandro and Sven Tarp (Eds.). 2009. Lexicography in the 21st Century. In Honour of Henning Bergenholtz: 161-178. Amsterdam/Philadelphia: John Benjamins.

Fuertes-Olivera, Pedro A. (Ed.). 2010. Specialised Dictionaries for Learners. Berlin/New York: De Gruyter. 
Fuertes-Olivera, Pedro A. Submitted. Translation Studies and The Literal Translation Hypothesis. Submitted for publication to META in 2012.

Fuertes-Olivera, Pedro A. and Ascensión Arribas-Baño. 2008. Pedagogical Specialised Lexicography: The Representatation of Meaning in English and Spanish Business Dictionaries. Terminology and Lexicography Research and Practice (TLRP) 11. Amsterdam/Philadelphia: John Benjamins.

Fuertes-Olivera, Pedro A., Pablo Gordo Gómez, Marta Niño Amo and Angel de los Rios Rodicio. 2010. Expert Knowledge and Translation Equivalents in the English-Spanish Accounting Dictionary. Caballero Rodríguez, Rosario and María Jesús Pinar Sanz (Eds.). 2010. Ways and Modes of Human Communication: 1083-1090. Ciudad Real: Universidad de Castilla la Mancha.

Fuertes-Olivera, Pedro A. and H. Bergenholtz (Eds.). 2011. e-Lexicography: The Internet, Digital Initiatives and Lexicography. London/New York: Continuum.

Fuertes-Olivera, Pedro A. and Sandro Nielsen. 2011: The Dynamics of Terms in Accounting: What the Construction of the Accounting Dictionaries Reveals about Metaphorical Terms in Culturebound Subject Fields. Temmerman, Rita and M. van Campenhoudt (Eds.). 2011. The Dynamics of Terms in Specialized Communication. An Interdisciplinary Perspective. Special Issue of Terminology. International Journal of Applied Issues in Specialized Communication 17(1): 157-180.

Fuertes-Olivera, Pedro A. and Marta Niño Amo. 2011. Internet Dictionaries for Communicative and Cognitive Functions: El Diccionario Inglés-Español de Contabilidad. Fuertes-Olivera, Pedro A. and H. Bergenholtz (Eds.). 2011. e-Lexicography: The Internet, Digital Initiatives and Lexicography: 168-186. London/New York: Continuum.

Fuertes-Olivera, Pedro A. and Sven Tarp. 2011. Lexicography for the Third Millennium: Cognitive-oriented Specialised Dictionaries for Learners. Ibérica. Journal of the European Association of Languages for Specific Purposes 21: 141-162.

Gottlieb, H. and J.E. Mogensen (Eds.). 2007. Dictionary Visions, Research and Practice. Amsterdam/ Philadelphia: John Benjamins. (Terminology and Lexicography Research and Practice 10.)

Gouws, Rufus H. 2004. Monolingual and Bilingual Learner's Dictionaries. Lexikos 16: 264-274.

Gouws, Rufus H. 2011. Learning, Unlearning and Innovation in the Planning of Electronic Dictionaries. Fuertes-Olivera, P.A. and H. Bergenholtz (Eds.). 2011. e-Lexicography. The Internet, Digital Initiatives and Lexicography: 17-29. London/New York: Continuum.

Halliday, M.A.K. 1975. Learning How to Mean. London: Edward Arnold.

Halverson, S.L. 1999. Conceptual Work and the 'Translation Concept'. Target 11(1): 1-31.

Halverson, S.L. 2002. Cognitive Models, Prototype Effects and Translation: The Role of Cognition in Translation (Meta)theory. Across Languages and Cultures 13: 21-43.

Hartmann, R.R.K. 2009. Keeping in Touch. A Survey of Lexicography Periodicals. Lexikos 19: 404422.

Hinkel, E. (Ed.). 2005. Handbook of Research in Second Language Teaching and Learning: 195-208. Mahwah, NJ: Lawrence Erlbaum Associates.

Leroyer, P. 2011. Change of Paradigm in Lexicography: From Linguistics to Information Science and from Dictionaries to Lexicographic Information Tools. Fuertes-Olivera, P.A. and H. Bergenholtz (Eds.). 2011. e-Lexicography. The Internet, Digital Initiatives and Lexicography: 121-140. London/New York: Continuum.

Mheta, G. and I. Muhwati. 2009. The Use of Loan Translation as a Term-Creation Strategy in Duramazwi reMimhanzi. Lexikos 19 Supplement: 150-156. 
Nielsen, S. 1994. The Bilingual LSP Dictionary. Principles and Practice for Legal Language. (Forum für Fachsprachen-Forschung 24.) Tübingen: Gunter Narr.

Nielsen, S. 2010. Specialised Translation Dictionaries for Learners. Fuertes-Olivera, Pedro A. (Ed.). 2010. Specialised Dictionaries for Learners: 69-82. Berlin/New York: De Gruyter.

Nielsen, Sandro and R. Almind. 2011. From Data to Dictionary. Fuertes-Olivera, P.A. and H. Bergenholtz (Eds.). 2011. e-Lexicography. The Internet, Digital Initiatives and Lexicography: 141-167. London/New York: Continuum.

Nielsen, S. and L. Mourier. 2007. Design of a Function-based Internet Accounting Dictionary. Gottlieb, H. and J. E. Mogensen (Eds.). 2007: 119-135.

Nielsen, S. and S. Tarp (Eds.). 2009. Lexicography in the 21st Century. In Honour of Henning Bergenholtz. Amsterdam/Philadelphia: John Benjamins.

Nkomo, D. 2008. Towards a Theoretical Model for LSP Lexicography in Ndebele with Special Reference to a Dictionary of Linguistic and Literary Terms. Master Thesis. University of Stellenbosh. Available at: https://scholar.sun.ac.za/bitstream/handle/10019.1/1954/Nkomo.D. pdf?sequence $=1$ [Last accessed: January, 20, 2011.]

Nord, C. 1997. Translating as a Purposeful Activity. Functionalist Approaches Explained. (Translation Theories Explained 1.) Manchester: St. Jerome.

Paltridge, B. and A. Phakiti (Eds.). 2010. Companion to Research Methods in Applied Linguistics. London: Continuum.

Schmidt, R. 1983. Interaction, Acculturation, and the Acquisition of Communicative Competence. Wolfson, N. and E. Judd (Eds.). 1983: 137-174.

Tarp, S. 2005. The Pedagogical Dimension of a Well-conceived Specialised Dictionary. Ibérica 10: 721.

Tarp, S. 2007. Lexicography in the Information Age. Lexikos 17: 170-179.

Tarp, S. 2008. Lexicography in the Borderland between Knowledge and Non-Knowledge. General Lexicographical Theory with Particular Focus on Learner's Lexicography. Lexicographica Series Maior 134. Tübingen: Max Niemeyer Verlag.

Tarp, S. 2009. Reflections on Data Access in Lexicographic Works. Nielsen, S. and S. Tarp (Eds.). 2009: 43-62.

Tarp, S. 2011. Lexicographical and Other e-Tools for Consultation Purposes: Towards the Individualization of Needs Satisfaction. Fuertes-Olivera, P.A. and H. Bergenholtz (Eds.). 2011. eLexicography. The Internet, Digital Initiatives and Lexicography: 54-70. London/New York: Continuum.

Teubert, W. 2005. Language as an Economic Factor: The Importance of Terminology. Barnbrook, G., P. Danielsson and M. Mahlberg (Eds.). 2005: 96-106.

Van Lier, L. 2005. Case Study. Hinkel, E. (Ed.). 2005: 195-208.

Wolcott, H.E. 1973. The Man in the Principal's Office. An Ethnography. New York: Holt, Rinehart \& Winston.

Wolfson, N. and E. Judd (Eds.). 1983. Sociolinguistics and Second Language Acquisition. Rowley, MA: Newbury House.

Yin, R.K. 2003. Case Study Research: Design and Methods Third edition. Thousand Oaks, CA: Sage Publications. 